
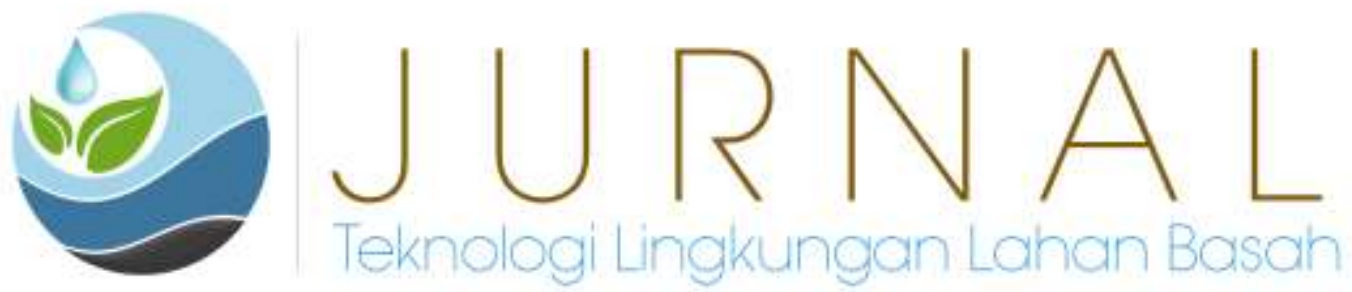

\title{
Pengolahan Air Gambut dengan Media Filter Keramik Berpori (Peat Water Treatment Using Portable Ceramic Filter Media)
}

\author{
Yudi Ayunata $^{1}$ Laili Fitria $^{1}$ Ulli Kadaria ${ }^{1}$ \\ ${ }^{1}$ Jurusan Teknik Lingkungan Universitas Tanjungpura
}

E-mail : yudiayunata@gmail.com

\begin{abstract}
Areas characteristic of the soil peaty usually contains brown water, PH (3-5), humus acid, organic substances, and high iron. In this research samples of raw water from the river agreed II which has a pH of 5.67, organic substances $232.17 \mathrm{mg} / \mathrm{L}$, color is $1,346 \mathrm{PT}-\mathrm{CO}$, and Iron Metal (Fe) is $0.96 \mathrm{mg} / \mathrm{L}$. Quality of the parameter is not qualified PERMESKES No 32 the year 2017 about hygiene sanitation and clean water. This study knows the effectiveness of porous ceramic filters with a mixture of eggshells, zeolite, and polyvinyl alcohol (PVA). Mixed variation of eggshell, zeolite, and PVA made is type (I) 67.5\%: $22.5 \%$ : $10 \%$, type (II) 45\%: 45\%: 10\%, and type (III) $22.5 \%: 67,5 \%: 10 \%$. Results showed a porous ceramic filter with a mixture of eggshells, zeolite, and PVA for each type filter (I), type (II), and type (III) have the density of 2, 092gr/CM3, 2, 080gr/CM3, 2, 006gr/Cm3. Porosity of $18 \%$, 43\%, and $69 \%$ as well as flux $1305 \mathrm{~L} / \mathrm{m}^{2}$.hour, $1813 \mathrm{~L} / \mathrm{m}^{2}$.hour, and $2209 \mathrm{~L} / \mathrm{m}^{2}$.hour. The highest color loss effectiveness in type Filter (II) $40 \%$ from 1001 TCU to 592.5 TCU. The type (I) effectiveness increases peat water $\mathrm{pH}$ from 5.67 to 6.84 by $17 \%$. The highest efficacy organic substances Parameter type (II) amounted to $77 \%$ from $232.17 \mathrm{mg} / \mathrm{L}$ to $51.64 \mathrm{mg} / \mathrm{L}$. turbidity of highest efficacy type (III) $48 \%$ of 29.6 $\mathrm{mg} / \mathrm{L}$ to $15.35 \mathrm{mg} / \mathrm{L}$. Iron Parameters Highest efficacy type (III) amounted to $53.12 \%$ from $0.96 \mathrm{mg} / \mathrm{L}$ to $0.45 \mathrm{mg} / \mathrm{L}$ and the highest effectiveness parameters of the type (III) of $78 \%$ from $139.44 \mathrm{mg} / \mathrm{L}$ to 59.91 $\mathrm{mg} / \mathrm{L}$.
\end{abstract}

Keywords: peat water, eggshells, ceramic filters, zeolite

\section{Abstrak}

Daerah karakteristik tanah bergambut biasanya mengandung air berwarna coklat, pH asam, memiliki kandungan asam humus, zat organik, dan besi yang tinggi. Dalam penelitian ini sampel air baku dari Sungai Sepakat II memiliki karakteristik pH 5,67, zat organik 232,17 mg/L, warna 1.346 pt-co, dan logam besi $(\mathrm{Fe}$ ) $0,96 \mathrm{mg} / \mathrm{L}$. Kualitas parameter tersebut tidak memenuhi syarat PERMESKES No 32 Tahun 2017. Penelitian ini untuk mengetahui efektivitas filter keramik berpori dengan campuran media cangkang telur, zeolit, dan Polivinil Alkohol (PVA) dalam pengolahan air gambut. Variasi campuran bahan cangkang telur, zeolit, dan PVA yang dibuat adalah Tipe (I) 67,5\%:22,5\%:10\%, Tipe (II) 45\%:45\%:10\%, dan Tipe (III) 22,5\%:67,5\%:10\%. Diketahui filter keramik berpori untuk filter Tipe (I), Tipe (II), dan Tipe (III) memiliki densitas sebesar 2,092 $\mathrm{gr} / \mathrm{cm}^{3}, 2,080 \mathrm{gr} / \mathrm{cm}^{3}, 2,006 \mathrm{gr} / \mathrm{cm}^{3}$. Porositas

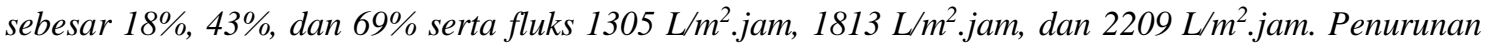
warna efektivitas tertinggi pada filter Tipe (II) 40\% dari 1001 TCU menjadi 592,5 TCU. Pada tipe (I) bisa meningkatkan pH air gambut dari 5,67 menjadi 6,84 dengan efektifitas sebesar 17\%. Penurunan parameter zat organik terjadi pada tipe (II), yakni sebesar 77\% dari 232,17 mg/L menjadi 51,64 mg/L. Penurunan kekeruhan tertinggi pada tipe (III) sebesar 48\% dari 29,6 mg/L menjadi 15,35 mg/L. Penurunan parameter besi tertinggi pada tipe (III) sebesar 53,12\% dari 0,96 mg/L menjadi 0,45 mg/L dan penurunan parameter kesadahan tertinggi juga pada tipe (III) sebesar $78 \%$ dari $139,44 \mathrm{mg} / \mathrm{L}$ menjadi 59,91 $\mathrm{mg} / \mathrm{L}$.

Kata Kunci: air gambut, cangkang telur, filter keramik, zeolit 


\section{PENDAHULUAN}

Kalimantan Barat merupakan wilayah yang memiliki lahan tanah gambut sekitar 1,73 juta hektar. Daerah yang karakteristik tanah bergambut biasanya mengandung air berwarna coklat, $\mathrm{pH}$ rendah, memiliki kandungan asam humus tinggi, zat organik dan besi (Fe) yang tinggi. Warna juga sekitar $1.001 \mathrm{pt}-\mathrm{co}$. Kualitas parameter tersebut tidak memenuhi syarat untuk keperluan higiene sanitasi dan air bersih (PERMESKES No 32 tahun 2017). Kadar pH normal yang diijinkan untuk air bersih berkisar antara 6,5-8,5, zat organik sebesar $10 \mathrm{mg} / \mathrm{L}$ dan warna adalah $50 \mathrm{TCU}$. Apabila air gambut ingin digunakan harus melalui pengolahan terlebih dahulu agar tidak berdampak pada kesehatan manusia.

Filter keramik berpori adalah keramik yang mempunyai rongga-rongga kecil sehingga dapat dilewati fluida (pori sekitar 30-70\%) serta dapat berfungsi sebagai media filter untuk menyaring partikel suspensi, koloid, logam berat, ion-ion tertentu, serta mikroorganisme seperti bakteri, kuman, parasit, dan jamur. Kelebihan filter keramik berpori adalah selain dapat menyerap fluida, filter keramik juga relatif lebih tahan terhadap perubahan suhu tinggi, korosi, dan kontaminasi bahan lain, sehingga dapat digunakan sebagai media filter. Kualitas filter keramik berpori sangat ditentukan oleh komposisi, ukuran partikel, dan suhu sinteringnya (Sebayang, 2009).

Berdasarkan uraian di atas maka dilakukan pembuatan filter keramik berpori yang terdiri dari kombinasi media cangkang telur, yang memiliki kandungan kalsium karbonat $\left(\mathrm{CaCO}_{3}\right)$ dan zeolit memiliki kandungan $\mathrm{Al}^{3+}$ dan $\mathrm{Si}_{4}$. Dilakukan perbandingan komposisi variasi massa campuran cangkang telur dan zeolit, sehingga diharapkan dapat menemukan komposisi filter keramik berpori. Komposisi berbandingan antara massa cangkang telur, zeolit, dan Polivinyl alcohol dengan perbandingan massa Tipe I 67,5\%:22,5\%:10\% (67,5 gram: 22,5 gram : 10 gram), Tipe II 45\%:45\%:10\% (45 gram: 45 gram: 10 gram), dan Tipe III 22,5\%:67,5\%:10\% (22,5 gram: 67,5 gram : 10 gram) dalam menurunkan parameter warna, $\mathrm{pH}$, zat organik, kesadahan dan besi (Fe) pada air gambut.

\section{METODE PENELITIAN}

a. Lokasi Pengambilan Sample Air Gambut

Air baku yang diolah menjadi air bersih adalah air permukaan yang berasal Parit Sepakat II Kelurahan Bansir Darat Kecamatan Pontianak Tenggara, Kalimantan Barat.

b. Alat dan Bahan

Adapun peralatan yang digunakan dalam penelitian ini adalah pipa $(\mathrm{d}=7.9 \mathrm{~cm}, \mathrm{t}=30$ $\mathrm{cm})$, modul filter cetakan $(\mathrm{d}=7.62 \mathrm{~cm}, \mathrm{t}=1 \mathrm{~cm}$, gelas ukuran $1000 \mathrm{ml}$, jerigen sampling 20 liter, saringan partikel (sieve) no. 45 dan no. 80, furnace, oven listrik, neraca digital, mortar batu dan kain halus bening, spectrophotometer, turbidimeter, dan $\mathrm{pH}$ meter, sedangkan bahan yang digunakan adalah sample air gambut 10 liter, aquades, Polivinyl alcohol 60 gram, cangkang telur 260 gram dan zeolite 260 gram dalam bentuk serbuk sebelum dihomogenkan.

c. Prosedur Penelitian

1. Tahap preparasi Media filter

Tahap pertama, ditimbang kebutuhan massa untuk 6 filter sebesar 260 gram cangkang telur, dicuci hingga bersih untuk menghilangkan kotoran dan daging 
telur yang menempel. Cangkang telur yang sudah bersih, direndam dengan air panas, kemudiaan dipanaskan menggunakan oven suhu $105{ }^{\circ} \mathrm{C}$ selama 30 menit (Musyrifahsyam, 2016). Cangkang telur yang sudah bersih dihaluskan menggunakan mortar batu yang dilapisi kain halus hingga berbentuk butiran halus. Tahap selanjutnya dilakukan pengayakan menggunakan dua pengayak (test-siever) yang disusun besar-kecil yaitu no. 40 (Ǿ $400 \mu \mathrm{m})$ dan no. 80 (ஜ́ 180 $\mu \mathrm{m})$. Serbuk cangkang telur yang akan digunakan adalah partikel yang lolos saring $400 \mu \mathrm{m}$ dan bertahan saringan $180 \mu \mathrm{m}$. Serbuk zeolit yang tergerus segera diayak hingga mendapatkan partikel zeolit yang lolos pada $400 \mu \mathrm{m}$ dan tertahan pada saringan partikel (sieve) $180 \mu \mathrm{m}$.

2. Tahap Pembuatan Filter Keramik

Berat total massa filter keramik untuk setiap tipe adalah 100 gram ditimbang dalam wadah cawan porselin dan ditimbang pula cangkang telur, zeolit, dan PVA sejumlah 67,5 gram : 22,5 gram : 10 gram, 45 gram : 45 gram : 10 gram, dan 22,5 gram: 67,5 gram : 10 gram secara berurutan masing-masing untuk tipe sampel filter keramik Tipe I, Tipe II dan Tipe III. Kemudian dimasukan ke dalam kantong plastik berperekat, dicampurkan kedua bahan cangkang telur dan zeolit yang sudah diayak serta ditambahan 10 gram Polivinyl alcohol. Kemudian ditambahkan sebanyak $50 \mathrm{ml}$ air (campuran cangkang telur, zeolit, dan PVA), Selanjutnya pencetakan filter keramik dilakukan dengan menuangkan pasta cangkang telur-zeolit ke dalam pipa berdiameter $7.62 \mathrm{~cm}$ dan ketebalan $1 \mathrm{~cm}$. Setelah itu, diamkan selama 3 hari pada suhu ruangan. Setelah itu, filter dikeluarkan dari cetakannya, kemudian dilanjutkan dengan pemanasan pada suhu $220{ }^{\circ} \mathrm{C}$ selama 6 jam dalam oven.

\section{d. Rangkaian Alat}

Alat dibuat menggunakan penyangga kayu yang digunakan sebagai dudukan untuk tabung filter. Filter keramik yang telah padat diletakkan dalam modul filtrasi yang dibuat dari pipa $\mathrm{d}=7,9 \mathrm{~cm}$ dan $\mathrm{t}=30 \mathrm{~cm}$ kemudian alat uji dirangkai, seperti Gambar 1.

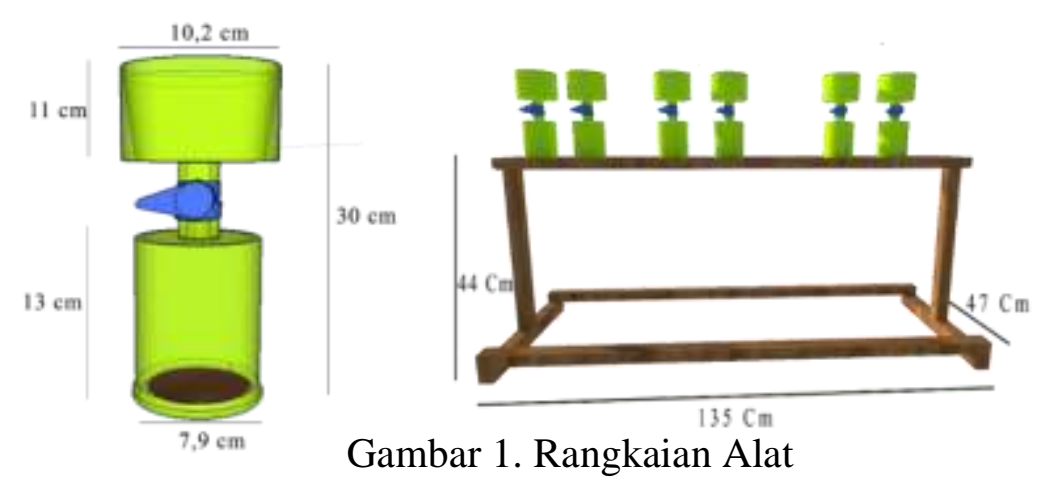

\section{HASIL DAN PEMBAHASAN}

1. Karakteristik fisik filter keramik

Adapun hasil pengukuran Karakteristik dengan persamaan (1), (2), (3), dan (4) dapat dilihat pada tabel 1 . 
Tabel 1.Karakteristik filter keramik

\begin{tabular}{|c|c|c|c|c|}
\hline $\begin{array}{c}\text { Tipe } \\
\text { Filter }\end{array}$ & $\begin{array}{c}\text { Densitas } \\
\left(\mathrm{gr} / \mathrm{Cm}^{3}\right) \\
(\rho)\end{array}$ & $\begin{array}{c}\text { Porositas } \\
(\%) \\
(\boldsymbol{\varepsilon})\end{array}$ & $\begin{array}{c}\text { Massa Susut } \\
(\%)\end{array}$ & $\begin{array}{c}\text { Fluks } \\
\left(\mathrm{L} / \mathrm{m}^{2} . \mathrm{jam}\right) \\
(\mathrm{J})\end{array}$ \\
\hline I & 2,092 & 18 & 4,41 & 1305 \\
\hline II & 2,080 & 43 & 5,19 & 1813 \\
\hline III & 2,006 & 69 & 8,56 & 2209 \\
\hline
\end{tabular}

Hasil pengukuran menunjukan densitas terbesar dicapai pada perbandingan komposisi cangkang telur dan zeolit pada perbandingan 22,5\%:67,5\%:10\% (Tipe filter III) yaitu sebesar $2,006 \mathrm{gr} / \mathrm{cm}^{3}$. Perbandingan $45 \%: 45 \%: 10 \%$ (Tipe filter II) memiliki densitas sebesar $2,080 \mathrm{gr} / \mathrm{cm}^{3}$, sedangkan pada perbandingan $67,5 \%$ : $22,5 \%$ : $10 \%$ (Tipe I) yaitu sebesar $2,092 \mathrm{gr} / \mathrm{cm}^{3}$. Hasil pengukuran porositas menunjukan nilai porositas tertinggi terdapat pada perbandingan komposisi cangkang telur dan zeolit 22,5\%:67,5\%:10\% (Tipe filter III) yaitu sebesar 69\%. Pada perbandingan $45 \%: 45 \%: 10 \%$ (Tipe filter II) didapati nilai porositas sebesar $43 \%$. Sedangkan nilai porositas terendah terdapat pada filter dengan perbandingan $67,5 \%$ : $22,5 \%$ : $10 \%$ (Tipe filter I) yaitu sebesar $18 \%$. Densitas dan porositas berhubungan satu sama lain, yaitu semakin besar densitas suatu benda akan memiliki rongga (pori) yang lebih kecil sehingga porositas yang dihasilkan akan semakin besar (Muclis, 2016).

Berdasarkan hasil analisis tersebut ditinjau dari ukuran pori, luas permukaan dan porositas filter keramik berpori yang dihasilkan pada penelitian ini, maka dapat ditentukan porositas yang baik pada filter keramik berpori yaitu tipe (III) dengan komposisi cangkang telur 22,5\% (22,5 gram), zeolit 67,5\% (67,5 gram) dan polivinil alkohol 10\% (10 gram).

2. Pengaruh perbandingan media filter keramik terhadap kualitas air gambut a. Warna

Hasil pengukuran parameter warna untuk masing-masing perbandingan komposisi filter keramik yaitu dapat dilihat pada Gambar 2.

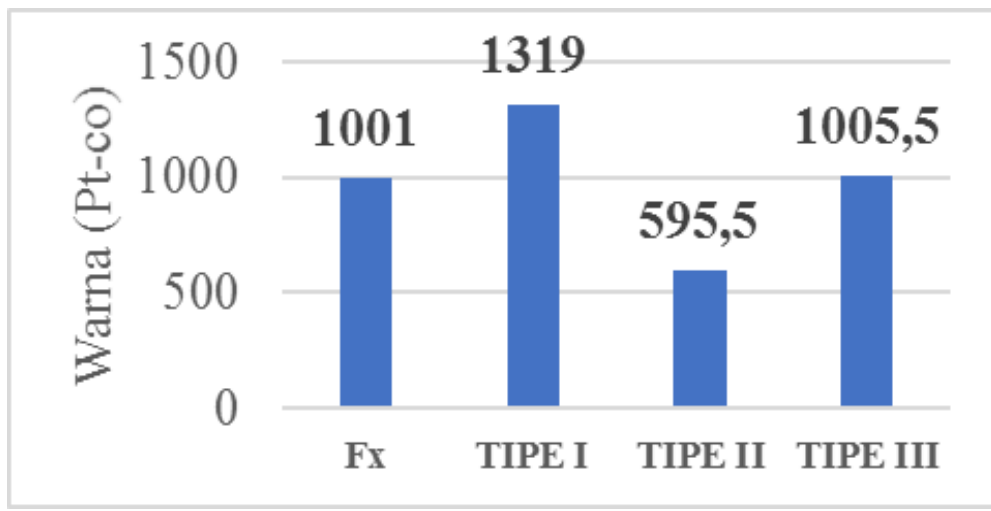

$\mathrm{Fx}=$ Konsentrasi awal (air baku Tipe I $=67,5 \%: 22,5 \%: 10 \%$ Tipe II $=45 \%: 45 \%: 10 \%$ Tipe III $=22,5 \%: 67,5 \%: 10 \%$

Gambar 2 . Grafik Perubahan Parameter Warna

Peningkatan konsetrasi warna pada filter tipe I dari nilai awal 1001 Pt-co menjadi $1319 \mathrm{Pt}$-co. Konsentrasi warna hasil tipe filter II mengalami penurunan yang signifikan dibandingkan kedua filter lainnya dan pada filter tipe III mengalami peningkatan kembali pada konsentrasi warna. Hal ini diakibatkan meningkatnya zat tersuspensi pada air hasil olahan yang disebabkan oleh kontribusi cangkang 
telur yang menyumbang ion $\mathrm{CaCO}_{3}$ yang berlebihan menyebabkan warna semu (Apparent Color) yang disebabkan oleh adanya bahan-bahan terlarut dan juga karena adanya bahan-bahan tersuspendi, termasuk diantaranya yang bersifat koloid (Fardiaz,1992).

b. $\mathrm{pH}$

Hasil pengukuran parameter $\mathrm{pH}$ untuk masing-masing perbandingan komposisi filter keramik yaitu dapat dilihat pada Gambar 3.

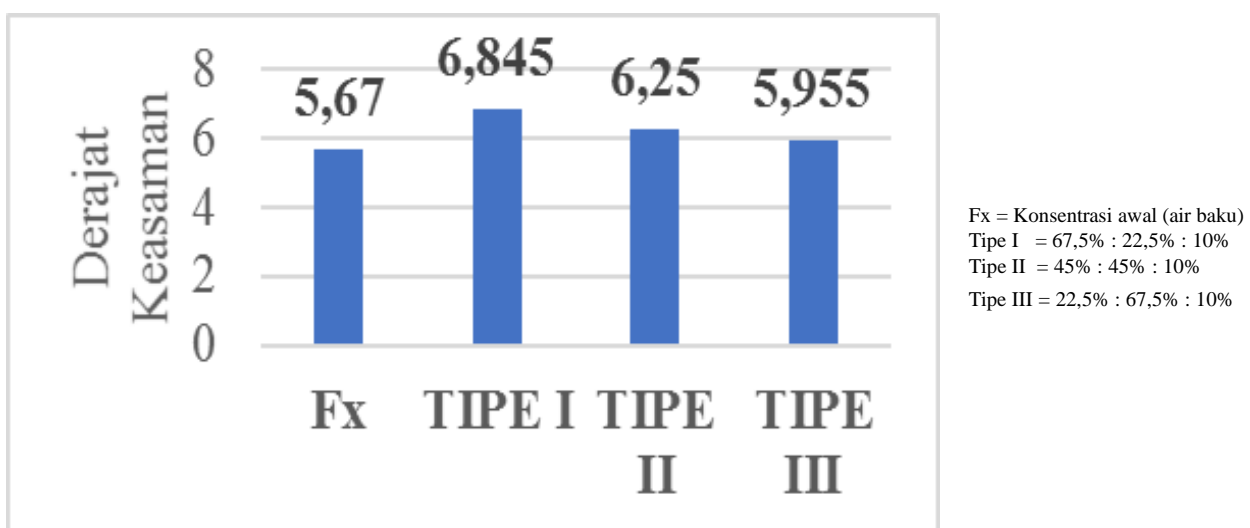

Gambar 3. Perubahan nilai pada Parameter Derajat Keasaman (pH)

Peningkatan nilai $\mathrm{pH}$ paling maksimum pada perbandingan komposisi cangkang telur dan zeolit sebesar 67,5\%:22,5\%:10\% (Tipe I) dimana $\mathrm{pH}$ awal 5,67 naik menjadi 6,84. Hal ini dikerenakan tipe filter I memiliki kandungan $\mathrm{CaCO}_{3}$ paling banyak dibandingkan tipe filter lainnya dengan cangkang telur 67,5\%. Cangkang telur mengandung $\mathrm{CaCO}_{3}$ dapat meningkatkan $\mathrm{pH}$ air. Menurut Awang-Hazmi ( 2007) yang jika $\mathrm{CaCO}_{3}$ dilarutkan dalam air, menyebabkan $\mathrm{CaCO}_{3}$ terurai berdasarkan reaksi :

$$
\mathrm{CaCO}_{3}(\mathrm{~s}) \longrightarrow \mathrm{Ca}^{2+}(\mathrm{aq})+\mathrm{CO}_{3}^{2-}(\mathrm{aq}) \quad \text { (Novita, 2008) }
$$

$\mathrm{CO}_{3}{ }^{2-}$ dalam air akan mengalami reaksi yaitu reaksi hidrolisis (penguraian air)

$$
\mathrm{CO}_{3}{ }^{2-}(\mathrm{aq})+2 \mathrm{H}_{2} \mathrm{O}(\mathrm{l}) \longrightarrow \mathrm{H}_{2} \mathrm{CO}_{3}(\mathrm{aq})+2 \mathrm{OH}^{-}(\mathrm{aq})
$$

Sedangkan $\mathrm{H}_{2} \mathrm{CO}_{3}$ akan langsung terurai menjadi $\mathrm{H}_{2} \mathrm{O}$ dan $\mathrm{CO}_{2}$ menurut reaksi :

$$
\mathrm{H}_{2} \mathrm{CO}_{3}(\mathrm{aq}) \longrightarrow \mathrm{H}_{2} \mathrm{O}(\mathrm{l})+\mathrm{CO}_{2}(\mathrm{~g}) \quad \text { (Prodjosantoso, 2011) }
$$

Oleh karena itu reaksi yang terjadi ketika kalsium karbonat direaksikan dengan air adalah :

$$
\mathrm{CaCO}_{3}(\mathrm{~s})+\mathrm{H}_{2} \mathrm{O}(\mathrm{l}) \longrightarrow \mathrm{Ca}(\mathrm{OH})_{2}(\mathrm{aq})+\mathrm{CO}_{2}(\mathrm{~g}) \text { (Mariyono, 2011) }
$$

Berdasarkan reaksi tersebut terbukti bahwa kalsium karbonat direaksikan dengai air akan melepaskan ion $\mathrm{OH}-$, sehingga jumlah $\mathrm{OH}$ - dalam air akan semakin banyak. Meningkatnya ion $\mathrm{OH}-$ dalam air gambut menjadi basa. Reaksi ini sesuai dengan teori asam basa Arrhenius yang menyatakan bahwa : suatu basa adalah senyawa yang melepaskan ion $\mathrm{OH}$ - dalam air sehingga air gambut yang awalnya bersifat asam setelah direaksikan dengan senyawa kalsium karbonat menghasilkan kalsium hidroksida $\left(\mathrm{Ca}(\mathrm{OH})_{2}\right)$ yang membuat $\mathrm{pH}$ air meningkat. 
c. Zat Organik

Hasil pengukuran parameter zat organik untuk masing-masing perbandingan komposisi filter keramik yaitu dapat dilihat pada Gambar 4.

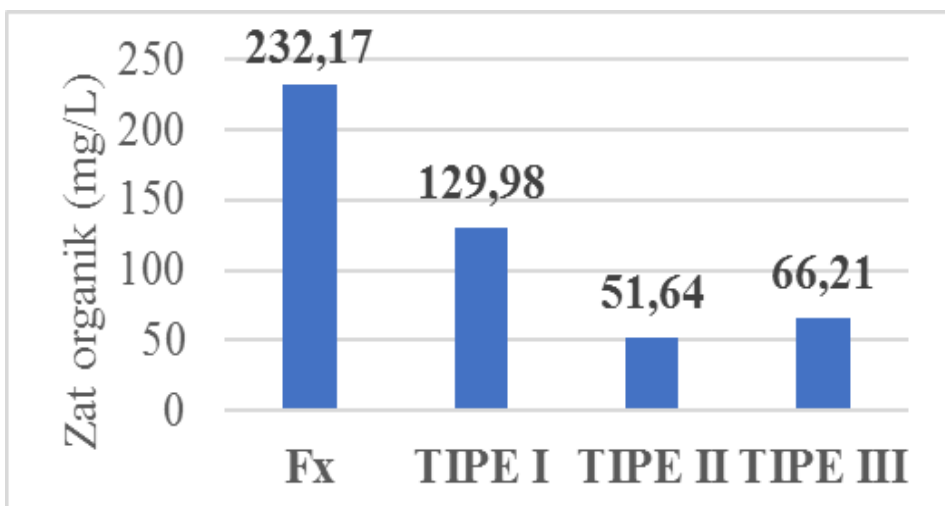

$\mathrm{Fx}=$ Konsentrasi awal (air baku) Tipe $\mathrm{I}=67,5 \%: 22,5 \%: 10 \%$ Tipe II $=45 \%: 45 \%: 10 \%$

Tipe III $=22,5 \%: 67,5 \%: 10 \%$

Gambar 4. Penurunan Parameter Zat organik

Penurunan parameter zat organik pada pengolahan menggunakan filter keramik signifikan yaitu penurunan filter tipe I dengan efektivitas $44 \%$ dari konsentrasi awal $232,17 \mathrm{mg} / \mathrm{L}$ menjadi $129,98 \mathrm{mg} / \mathrm{L}$. Pada filter tipe III efektivitas $71 \%$ dari konsentrasi awal 232,17 mg/L menjadi $66,21 \mathrm{mg} / \mathrm{L}$. Sedangkan filter tipe II memiliki efektivitas paling tinggi sebesar $77 \%$ dari konsentrasi awal $232,17 \mathrm{mg} / \mathrm{L}$ menjadi 51,64 mg/L. Penurunan zat organik pada setiap filter disebabkan adanya proses proses ion exchanger dan adsorsi media zeolit.

d. Kekeruhan

Hasil pengukuran parameter kekeruhan masing-masing perbandingan komposisi filter keramik dapat dilihat pada Gambar 5.

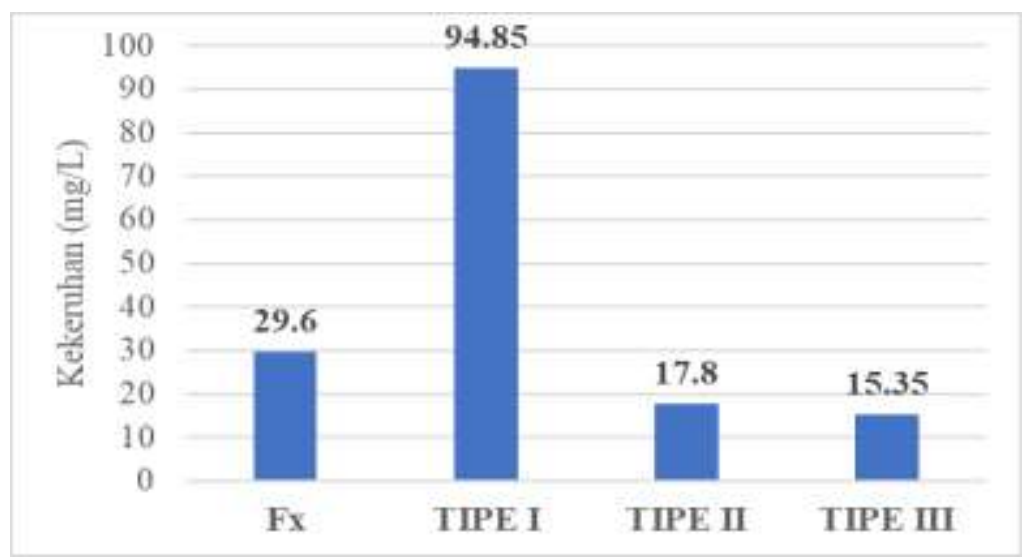

$\mathrm{Fx}=$ Konsentrasi awal (air baku) Tipe I $=67,5 \%: 22,5 \%: 10 \%$ Tipe II $=45 \%: 45 \%: 10 \%$ Tipe III $=22,5 \%: 67,5 \%: 10 \%$

Gambar 5. Penurunan Parameter Kekeruhan

Pengolahan air gambut menggunakan filter keramik dengan campuran cangkang telur dan zeolit dengan parameter kekeruhan pada tipe filter (I) mengalami peningkat konstrasi awal 29,6 mg/L menjadi 94,89 mg/L, Peningkatan kekeruhan pada filter tipe (I) yang tinggi disebabkan suspensi-supensi menempel pada poripori filter keramik sehingga menyebab Blockage. Blockage terjadi ketika diameter dari foulant sama besarnya dengan besar dari pori pori dari filter keramik. 
e. Besi

Hasil pengukuran parameter besi (Fe) untuk masing-masing perbandingan komposisi filter keramik yaitu dapat dilihat pada Gambar 6.

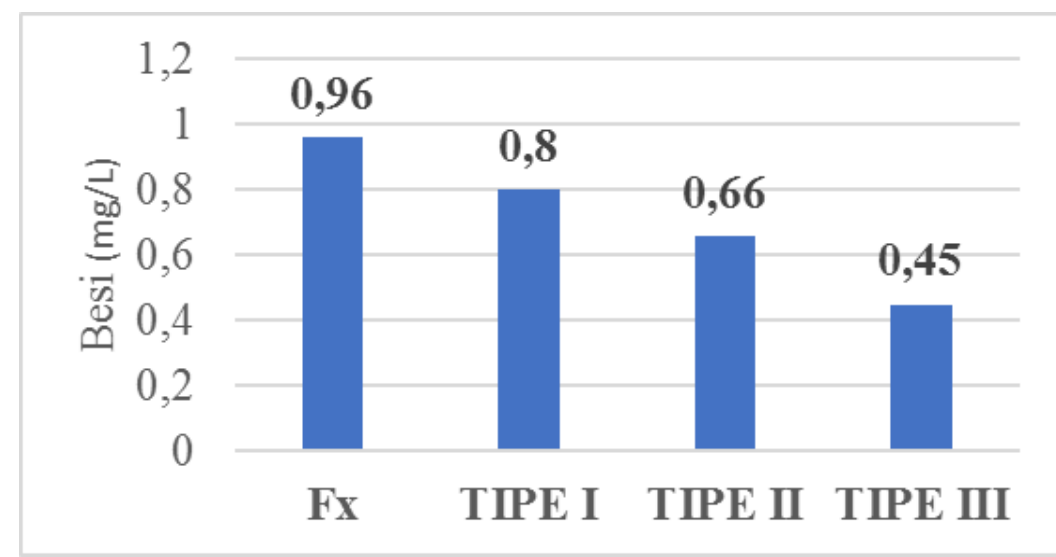

$\mathrm{Fx}=$ Konsentrasi awal (air baku) Tipe I $=67,5 \%: 22,5 \%: 10 \%$ Tipe II $=45 \%: 45 \%: 10 \%$ Tipe III $=22,5 \%: 67,5 \%: 10 \%$

Gambar 6. Penurunan Parameter Besi

Penurunan besi paling tinggi pada pengolahan menggunakan filter keramik dengan tipe filter III, efektivitas sebesar 53,12\% dengan konsentrasi awal 0,96 $\mathrm{mg} / \mathrm{L}$ menjadi $0,45 \mathrm{mg} / \mathrm{L}$, pada tipe II efektivitas $31,25 \%$ dengan konsentrasi awal $0,96 \mathrm{mg} / \mathrm{L}$ menjadi $0,66 \mathrm{mg} / \mathrm{L}$, dan pada filter tipe I sebesar $16,66 \%$ dengan konsentrasi awal $0,96 \mathrm{mg} / \mathrm{L}$ menjadi $0,8 \mathrm{mg} / \mathrm{L}$, sehingga tidak terlalu signifikan. Hal dikarenakan komposisi filter tipe (II) dan filter tipe (III) memiliki jumlah perbandingan zeolit lebih banyak dibandingkan tipe (I), dimana zeolit memiliki peran penting dalam proses penurunan Besi $(\mathrm{Fe})$.

Penggunaan zeolit sebagai basis filter yang telah banyak dilakukan. Misalnya Rahman dan Hartono (2004) menggunakan zeolit alam tanpa perlakuan khusus untuk menurunkan konsentrasi $\mathrm{Fe}^{2+}$ dalam sampel air tanah untuk keperluan air minum dan berhasil menurunkan konsentrasinya hingga $50 \%$. Istadi dkk (2006) melakukan pemisahan $\mathrm{Fe}^{2+}$ menggunakan zeolit alam dan hasilnya mampu menurunkan konsentrasi Fe2+ hingga 92,3\%. Selain itu, Saifudin dan Astuti (2005) menggunakan zeolit yang dikemas dalam bentuk kolom membran berhasil menurunkan kadar $\mathrm{Fe}^{2+}$ air sumur hingga $94 \%$. Menurut (Rahmawati dan Sugito, 2015) penurunan konsentrasi (Fe) menggunakan media zeolit berhasil mereduksi Fe sebesar $75 \%$.

f. Kesadahan

Hasil pengukuran parameter kesadahan untuk masing-masing parameter perbandingan komposisi filter keramik yaitu dapat dilihat pada Gambar 7.

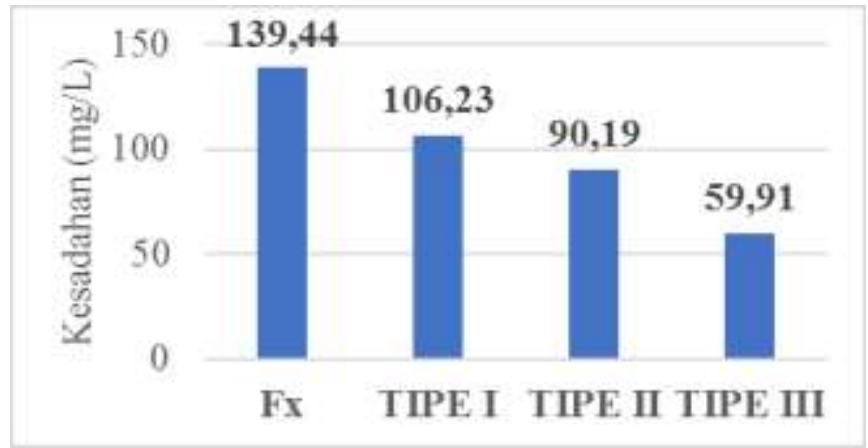

$\mathrm{Fx}=$ Konsentrasi awal (air baku)

Tipe I $=67,5 \%: 22,5 \%: 10 \%$

Tipe II $=45 \%: 45 \%: 10 \%$

Tipe III $=22,5 \%: 67,5 \%: 10 \%$

Gambar 7. Penurunan Parameter Kesadahan 
Pengolahan air gambut menggunakan filter keramik dengan campuran cangkang telur dan zeolit dengan parameter kesadahan pada tipe filter I memiliki efektivitas $23,81 \%$ dengan konsentrasi awal 139,44 mg/L menjadi $106,23 \mathrm{mg} / \mathrm{L}$, filter keramik tipe II didapatkan efektivitas sebesar 35,31\% dengan konsentrasi awal 139,44 mg/L menjadi 90,19 $\mathrm{mg} / \mathrm{L}$. Pada filter tipe III penurunan parameter kesadahan paling tinggi sebesar 57\% dengan konsentrasi awal 139,44 mg/L. Adanya peningkatan efektivitas pada tipe (II) dan tipe (III) disebabkan peranan penting zeolit dalam menurunkan kesadahan, hal ini karena massa lebih besar dibandingkan pada filter tipe (I). Adapun reaksi yang terjadi pada saat proses pelunakan air sadah berlangsung oleh bantuan zeolit adalah sebagai berikut :

$$
\begin{aligned}
& \mathrm{Na}_{2} \mathrm{Z}+\mathrm{Ca}^{2+} \longrightarrow \mathrm{CaZ}+2 \mathrm{Na}^{+} \\
& \mathrm{Na} 2 \mathrm{Z}+\mathrm{Mg}^{2+} \longrightarrow \mathrm{MgZ}+2 \mathrm{Na}^{+} \text {(Marsidi, 2001) }
\end{aligned}
$$

Zeolit merupakan bahan untuk pelunakan air sadah, selain itu juga terjadi pertukaran ion oleh media filter zeolit dalam mengikat kalsium. zeolit juga mudah melepaskan kation dan digantikan dengan kation lainnya, misalnya zeolit melepas natrium dan digantikan dengan mengikat kalsium atau magnesium. Dengan demikian, zeolit berfungsi sebagai ion exchanger dan adsorben dalam pengolahan air (Kusnaedi, 2010).

\section{PENUTUP}

Berdasarkan hasil penelitian ini dapat disimpulkan: filter keramik berpori dengan campuran cangkang telur, zeolite dan PVA, masing-masing filter Tipe (I) 67,5 \%: 22,5 $\%: 10 \%$, Tipe (II) $45 \%: 45 \%: 10 \%$, dan Tipe (II) $22,5 \%: 67,5 \%: 10 \%$, memiliki densitas sebesar 2,092 $\mathrm{gr} / \mathrm{cm}^{3}, 2,080 \mathrm{gr} / \mathrm{cm}^{3}, 2,006 \mathrm{gr} / \mathrm{cm}^{3}$. Porositas sebesar $18 \%, 43 \%$, dan $69 \%$ serta Fluks $1305 \mathrm{~L} / \mathrm{m}^{2}$.jam, $1805 \mathrm{~L} / \mathrm{m}^{2}$.jam, dan $2209 \mathrm{~L} / \mathrm{m}^{2}$.jam.

Pengolahan air gambut dengan filter keramik berpori terjadi penurunan parameter warna dengan efektivitas tertinggi pada filter Tipe II, yakni 40\% dari 1001 TCU menjadi 592,5 TCU. Pada Tipe I, cukup efektif dalam meningkatkan $\mathrm{pH}$ yakni dari 5,67 menjadi 6,84 sebesar 17\%. Pada parameter zat organik, efektivitas tertinggi pada tipe II, sebesar $77 \%$ dari $232,17 \mathrm{mg} / \mathrm{L}$ menjadi $51,64 \mathrm{mg} / \mathrm{L}$. Penurunan parameter kekeruhan terjadi pada pengolahan dengan filter keramik Tipe III sebesar $48 \%$, dari $29,6 \mathrm{mg} / \mathrm{L}$ menjadi 15,35 $\mathrm{mg} / \mathrm{L}$. Untuk parameter besi, efektivitas tertinggi juga pada Tipe III sebesar 53,12\% dari $0,96 \mathrm{mg} / \mathrm{L}$ menjadi $0,45 \mathrm{mg} / \mathrm{L}$ dan untuk parameter kesadahan efektivitas tertinggi terjadi pada filter keramik Tipe III, yakni sebesar 78\% dari 139,44 mg/L menjadi 59,91 $\mathrm{mg} / \mathrm{L}$.

\section{UCAPAN TERIMA KASIH}

Terima kasih kepada dosen pembimbing skripsi, Ibu Laili Fitria dan Ulli Kadaria, dosen penguji skripsi, Bapak Kiki Prio Utomo dan Ibu Herda Desmaiani, serta semua pihak yang terlibat dan membantu penulis selama proses pengerjaan penelitian yang tidak dapat diucapkan satu persatu.

\section{DAFTAR PUSTAKA}

Akbar, M. Ali. 2010. Pembuatan Membran Mikrofilter Zeolit Alam dengan Penambahan Semen putih Portland. Jakarta: UIN Syarif Hidayatullah.

Amo, A. B. (2005). Pengaruh bubuk kulit telur pada potensi stabilisasi kapur pada tanah lempung ekspansif. Res. J. Agric dan Biol. Sci, 1:. 80-84. 
Amrullah, I. K. (2003). Nutrisi Ayam Petelur. Bogor: Lembaga Satu Gunung Budi.

Anggito P. Tetuko, dkk. 2007. Pembuatan dan Karakterisasi Keramik Berpori dari Tanah Liat dan Limbah Lumpur Padat (Sludge) Untuk Aplikasi Filter Air. Prosiding Seminar Nasional Metalurgi dan Material, Departemen Metalurgi dan Material. Depok: Ui.

Sebayang, Perdamean dan Anggito P. Tetuko, 2006. Pengaruh Penambahan Serbuk Kayu Terhadap Karakteristik Keramik Cordierite Berpori Sebagai Bahan Filter Gas Buang. Prosiding Simposium Fisika Nasional XXi, Makasar 13-14 September 2006.

Sengphet KD, Pasomsouk K, Sato T, Ahmad FN, Radzali O. Fabrication of Porous Clay Ceramics Using Kenaf Powder Waste. International Journal of Scientific and Research Publications. 2013; III(8).

Shaafsma, P. D. (2002). Positive effect of chicken eggshell powderused vitamin-mineral supplement on frmorl neck bone minerl density in healthy late post menopausal dutch women. Jurnal of nutritien, (8),267-275.

Sundaryani, S. (2000). Pembibitan Ayam Ras. Jakarta: Penerba Swadaya.

Sutrisno, T. (1991). Teknologi Penyediaan Air Bersih. Rineka Cipta. Jakarta: Rineka Cipta.

Sutrisno, T. (2006). Teknologi Penyediaan Air Bersih. Jakarta: Rhineka Cipta.

Watanabe, Y. T. (2004). Hydrothermal formtion of hydroxyapatite layers on the surface of type-a zeolite. Journal of American Ceramic Society, 87(7),1395-1397.

Yuwanta, T. (2010). Telur dan Kualitas Telur. Yogyakarta: Gadjah Mada University Press. 